\title{
The Sources of Worker Anxiety: Evidence From the Michigan Survey
}

\author{
Maria Ward Otoo \\ Board of Governors of the Federal Reserve System \\ Division of Research and Statistics, Mail Stop 80 \\ Washington, D.C. 20551 \\ email: m1mwo00@frb.gov \\ phone: (202) 452-2236, fax: (202) 452-5296
}

September 1997

\begin{abstract}
This paper uses individual responses from the Michigan SRC survey of consumer attitudes to examine worker anxiety. It identifies "anxious" households (those that express some concern about the job security) and analyzes some factors that might be driving this angst. It found that a little more than a quarter of households revealed concerns about job security. Also, the results suggest that less educated households (those lacking a high school diploma) were significantly more likely to be concerned about job loss as were black and Asian households.

Geographic factors were important in driving worker anxiety with largely households along the East Coast and West Coast significantly more likely to express concern over job security. The results also indicated that hearing news about layoffs or plant closings increased the likelihood that an employed household was anxious, and anxious households were more likely to hold unfavorable views on the overall economy, although the relationship was far from certain. This leaves room for the possibility that households could report favorable views about the economy in general yet harbor significant concerns about their own job security. The results also suggested that anxious, employed households might be more reluctant to take on more debt. However, job anxiety did not appear to have any impact on households' views on using savings to finance consumption. Finally, the results suggest that worker anxiety was higher in 1995 than in the late 1980 s.
\end{abstract}

My thanks to Bruce Fallick, Martha Starr-McCluer, Spencer Krane, Karen Dynan, Charles Fleisman, Charles Struckmeyer, and participants at the annual Eastern Economic Association meetings for helpful comments. The views expressed in this paper are my own and do not necessarily reflect the views of the Federal Reserve System. 


\section{Introduction}

Worker anxiety has received a good deal of attention in the press in recent years. Opinion polls indicate continued disquiet amongst workers even at a time of general overall economic health. For example, by early 1996, the civilian unemployment rate had tumbled to 5.6 percent from a recent high of 7-1/2 percent in 1992. Yet, in March of that year, the New York Times ran a series of articles under the title, "The Downsizing of America." ${ }^{1}$ The series highlighted workers from various occupations and income levels who had lost jobs due to restructuring or downsizing in their respective companies. For the series, the Times conducted a poll that indicated that 45 percent of respondents were "very worried" or "somewhat worried" they (or a member of their household) could be out of work in a year. Such a high response seemed at odds with an economy in which more than 94 percent of the labor force was employed.

Why the interest in worker anxiety? For those who track public opinion, the topic is interesting in its own right. When considered in an economic context, concern over possible job loss could affect an individual's employment and consumption behavior. Anxious workers might save more or pursue wage increases less vigorously. If current levels of anxiety represent a structural shift, then one might see a higher saving rate or lower wage inflation at a given level of economic activity than might otherwise have been the case. This paper attempts to identify anxious workers and determine what factors might be driving this angst.

I use information on individual responses from the Michigan Survey Research Center's (SRC) survey of consumers to identify "anxious" households and examine the importance of demographic and geographic factors on their anxiety. I also test the importance of news reports on households' job anxiety and how employment insecurity effects views of overall economic activity and spending behavior.

The organization of the paper is as follows: The next section discusses worker anxiety and some recent work on the topic. Section 3 provides empirical results. The final section summarizes the results and discusses areas for further work.

${ }^{1}$ March 3, 1996 through March 9, 1996. 


\section{Defining Worker Anxiety and the Factors that Drive It}

\subsection{What is "Worker Anxiety?"}

It is difficult to define worker anxiety as it is used in the popular press. In applied work, economists most frequently deal with measurable outcomes. Whereas, anxiety reflects the subjective probability or perception of job loss for oneself or a family member. One could be concerned about job loss due to personal characteristics--for example, poor job performance. However, current discussions of worker anxiety concentrate more on external causes of job insecurity outside of cyclical fluctuations that are not closely tied to an individual's job performance. One could be laid off due to some technological innovation. Or one's office or factory could be relocated or "downsized" even if the operation is profitable.

The Michigan Survey Research Center has been monitoring households' perceptions on a variety of topics since the 1940s and now collects data monthly. The Conference Board also conducts a monthly survey of consumers' attitudes. However, neither of these surveys asks respondents explicitly about their views on possible job loss. ${ }^{2}$ Since 1994 , the Survey of Economic Expectations conducted by the Letters and Science Survey Center at the University of Wisconsin-Madison has conducted a periodic survey that asks individuals explicitly their probability of job loss over the next twelve months as well as other questions to measure anxiety over crime and health care coverage. Dominitz and Manski (1996) analyzed results from this survey and found that the median probability of job loss was 0.05 with a mean probability of 0.18 . Their results highlight a couple of factors. First, individuals appear able to correctly perceive their risks of job loss. Using data from the Current Population Survey, I estimated a mean probability of 0.18 and a median probability of 0.06 of being currently unemployed or not in the labor force. ${ }^{3}$ Although far from conclusive, it suggests that job

\footnotetext{
${ }^{2}$ Both surveys ask respondents their views on employment or unemployment for the economy as a whole but not for the individual.

${ }^{3}$ I estimated the probability that a household was currently unemployed or out of the labor force; whereas, the Wisconsin survey is forward looking, and asks individuals for their probability of unemployment over the next 12 months.
} 
anxiety is not the result of individuals having subjective probabilities of employment wildly out of line with reality. In addition, the Wisconsin survey did not reveal widespread concern about job loss. Rather, their results indicate that the vast majority of individuals place a low probability on the event; while a small subset of individuals perceive very high risks. These results seem at odds with poll results like the one from the New York Times that suggested job anxiety to be fairly broadly based.

In the Michigan survey, individuals are asked their perceptions of their family's income and views on business conditions, unemployment, and buying conditions. However, Michigan survey data published in recent years do not reveal much anxiety--job or otherwise. Chart 1 shows measures of consumer confidence from both the Michigan and Conference Board surveys. By early 1996, both indices had climbed to levels that matched or exceeded those of the late 1980s. Nevertheless, the Michigan data contain information that can be used to better understand worker anxiety. For example, the survey asks:

We are interested in how people are getting along financially these days. Would you say that you (and your family living there) are better off or worse off financially than you were a year ago? (Surveys of Consumers, December 1996)

For those answering that they are worse off financially, the interviewer asks for their reasons with two of their responses recorded in the survey. A respondent could answer that the households was worse off financially because of lower investment returns, and this would be recorded. Another possible response is to state that one's job is less secure. When an individual responded in this way, I defined that household as "anxious." That is, a household that expressed concern over job security. Anxious households that were identified in this manner embody the strictest definition of anxiety. However, other questions were used as well to identify anxious households since responses to these questions also touched on job security--although not in as individual a sense as the job insecurity response to the above question. Appendix A has the complete list of questions with the responses that I used to identify "anxious" households. Of the total sample, a little more than a quarter of households expressed concern over job security. 
A plus of using the Michigan data is that individuals reveal their concerns about job security. Thus, there is less of a possibility that their responses could be influenced by leading questions. In addition, their concerns must be quite potent to be reflected in the survey responses. However, there are some drawbacks. The data do not indicate why an individual might be concerned about his job, and the survey no longer collects information on the employment status of the household. Not only does this make it difficult to identify anxious workers but one also lacks information on the industry and occupation of employed individuals. However, since the focus of this study is on worker anxiety, I first had to identify employed households. To do this, I used data from the Current Population Survey (CPS) that is published monthly by the Bureau of Labor Statistics (BLS). Using these data, I constructed a model that could discriminate between households likely to be employed and those that were unemployed or not in the labor force (NILF). I then used the estimated coefficients from this model along with data from the Michigan survey to estimate the probability of employment for a Michigan survey household. A Michigan survey household with an estimated probability of employment of 0.5 or more was considered employed.

\subsection{Identifying Employed Households in the Michigan Survey}

In the Michigan survey, the respondent (an individual aged 18 or more) is asked his or her perceptions of economic conditions and family financial situation. Thus, the survey captures the opinions of a single individual who is assumed to reflect the views of the entire household. For this reason, I defined the unit of observation in the Michigan survey as the household rather than the individual. Although the Michigan survey does not ask about the employment status of household members, it does contain demographic information, including household income. I used corresponding variables contained in the CPS along with its information on labor market status to generated a model capable of assigning each household in the Michigan survey a probability of being employed--that is, having at least one wage earner aged 21 or more. The alternative to being an employed household was to be unemployed or NILF. For this study, unemployment and NILF were treated as the same 
state. ${ }^{4}$ Any household with an assigned probability of employment of 0.5 or more was considered employed.

Separating individuals into one population or another can be done with discriminant analysis; however, Press and Wilson (1978) demonstrated that logistic analysis is generally more robust, so I employed the logistic model. I used data from the March 1995 CPS, which contained 149,642 individual observations comprising 56,941 households. A total of 1,125 households were dropped because they contained no individual who was at least age 21 or because of incomplete information, which left 55,816 observations. The probability that household $\mathrm{i}$ is employed is given by:

$$
P_{i}=1 /\left(1+e^{x_{i}^{\prime} B}\right),
$$

with:

$$
\begin{aligned}
& \mathrm{X}_{\mathrm{i}}{ }^{\mathrm{B}} \mathrm{B}=\mathrm{B}_{1}+\mathrm{B}_{2} \mathrm{INCOME}_{\mathrm{i}}+\mathrm{B}_{3} \mathrm{NOHOME}_{\mathrm{i}}+\mathrm{B}_{4} \mathrm{UNR}_{\mathrm{i}}+\mathrm{B}_{5} \mathrm{NOKIDS}_{\mathrm{i}}+\mathrm{B}_{6} \mathrm{CITY} \\
& +\mathrm{B}_{7} \mathrm{NOMSA}_{\mathrm{i}}+\mathrm{B}_{8} \mathrm{YOUTH}_{\mathrm{i}}+\mathrm{B}_{9} \mathrm{OLDER}_{\mathrm{i}}+\mathrm{B}_{10} \mathrm{MATURE}_{\mathrm{i}}+\mathrm{B}_{11} \mathrm{BLACK}_{\mathrm{i}} \\
& +\mathrm{B}_{12} \mathrm{HISP}_{\mathrm{i}}+\mathrm{B}_{13} \text { INDIAN }_{\mathrm{i}}+\text { B }_{14} \text { ASIAN }_{\mathrm{i}}+\mathrm{B}_{15} \mathrm{OTHER}_{\mathrm{i}}+\text { B }_{16} \text { NO_HS }_{\mathrm{i}} \\
& + \text { B }_{17} \mathrm{HIGH}_{-} \mathrm{SCHOOL}_{\mathrm{i}}+\mathrm{B}_{18} \mathrm{SOME}_{-} \mathrm{COLL}_{\mathrm{i}}+\mathrm{B}_{19} \mathrm{NOMARRY}_{\mathrm{i}}+\mathrm{B}_{20} \mathrm{DIV}_{-} \mathrm{SEP}_{\mathrm{i}} \\
& +\mathrm{B}_{21} \mathrm{FEMALE}_{\mathrm{i}}+\text { regional dummy variables. }
\end{aligned}
$$

The $B_{i}$ coefficients are to be estimated. The variable definitions are contained in table 1 along with sample means. Since the coefficients from the logistic model are interpreted in relative terms, the above model can be viewed as estimating the probability of employment relative to a household in which the respondent was a college educated, prime age (25 to 54 ), married, white male with children who is a home owner and lives in the suburbs of a

\footnotetext{
${ }^{4}$ Previous studies have found support for the treatment of unemployed and NILF as the same state--particularly for young men. See Clark and Summers (1982), Flinn and Heckman (1982), and Gönül (1992).
} 
metropolitan area in the South Atlantic census region. ${ }^{5}$

Equation (1) was estimated using a maximum likelihood procedure and the results are shown in table 2. For the most part, the results generally conform to prior notions about employment status. The higher one's reported family income, the greater the likelihood that the household has at least one employed adult. Similarly, the higher one's local unemployment rate (UNR), the lower the probability of employment. Other variables that had a significant, negative impact on the likelihood of employment included lack of home ownership (NOHOME), low education (NOHS), living in a center city (CITY), and being 55 or older, female, or a Native American. Of the geographic areas, living in census region 2 (New York, New Jersey and Pennsylvania) significantly lowered one's probability of employment relative to someone in region 5. However, those in region 4 (Iowa, Kansas, Minnesota, Missouri, Nebraska, and the Dakotas) and region 7 (Arkansas, Louisiana, Oklahoma, and Texas) were more likely to be employed. None of the other census regions had a significant impact on the likelihood of employment.

In order to generate employment probabilities for households in the Michigan survey, I used the estimated coefficients shown in table 2 along with comparable data from the Michigan survey to obtain an estimate of the employment probability of each household in the Michigan data set. That is, I first generated:

$$
z_{i}=\sum_{i=0}^{29} \beta_{i} X_{i}
$$

The $\beta_{i}$ are the estimated coefficients of the logit model shown in table 2 , and the $X_{i}$ are the corresponding series from the Michigan data set. With the Z's in hand, the probability of employment for each Michigan household was simply: $\operatorname{PROBE}_{\mathrm{i}}=\mathrm{e}_{\mathrm{i}}^{\mathrm{z}} /\left(1+\mathrm{e}_{\mathrm{i}}^{\mathrm{z}}\right)$.

The Michigan data covered the period of June through December 1995, excluding September, for a total of 3,012 observations; however, 280 observations were dropped because the respondent was less than age 21 or because of incomplete information. This left

\footnotetext{
${ }^{5}$ The South Atlantic (fifth census) region includes Delaware, Maryland, West Virginia, the District of Columbia, Florida, Georgia, and the Carolinas.
} 
a total of 2,732 observations. Employment probabilities were estimated for each of these observations and the results are shown in Chart 2, which plots the distribution of employment probabilities for households in the Michigan survey and the CPS using weighted data from each. Results using the two surveys are quite similar. The model ascribed an employment probability of at least 0.9 to about 60 percent of the households from both surveys. The skewed employment distribution suggests that the model was able to discriminate fairly easily between employed and unemployed/NILF households.

All households with a probability of employment equal to or greater than 0.5 were considered employed for the purposes of this study. This implied that 85 percent of households were employed in the Michigan survey (using weighted data). Data from the CPS indicated that 78 percent of these households were employed (using weighted data).

\section{Empirical Results}

\subsection{Determining the Factors that Drive Worker Anxiety}

As mentioned previously, Appendix A contains a complete list of the questions used to identify "anxious" households. Using the responses to the questions listed in the appendix, I identified a total of 604 "anxious" households from the total of 2,334 employed households or about 26 percent using unweighted data. ${ }^{6}$ Amongst all households, about 27 percent were anxious.

I sought to answer three broad questions about worker anxiety. The first was whether anxious households were demographically different from households that did not express a concern over job security. Also of interest is how important news stories of layoffs or plant closings are in driving anxiety. The final issue examined was if there is a dichotomy in how anxious households view their situation versus the economy in general. Anxious households could harbor favorable views on the overall economy, but still be concerned about their own job security. This might explain why overall measures of consumer confidence are high, yet job security remains an ongoing concern.

\footnotetext{
${ }^{6}$ Using weighted data, about 27 percent of the employed Michigan sample is anxious.
} 
In order to analyze worker anxiety, I estimated a logit model where the probability of being an employed, anxious household is:

$$
P_{i}=1 /\left(1+e^{x_{i}^{\prime} \Gamma}\right)
$$

with $\Gamma$ as a vector of coefficients to be estimated.

The list of explanatory variables contained in $\mathbf{X}_{\mathbf{i}}$ is shown in table 3 . The set of explanatory variables includes a number of series to control for demographic factors, which include the age of the respondent (YOUTH, OLDER, MATURE), whether the household contains any children (NOKIDS), household income (INCOME), marital status of the respondent (NOMARRY, DIV_SEP), race/ethnicity (BLACK, HISP, INDIAN, ASIAN, OTHER), sex (FEMALE), and the education of the respondent (NO_HS, HIGH_SCHOOL, SOME_COLL). Lack of home ownership might be a factor in driving anxiety (NOHOME) as might a decrease in home value (NOVALUE). The variable, UNR, is the average 1995 civilian unemployment rate for the household's MSA and was included to control for different local labor market conditions. Each household was matched to a local MSA unemployment rate. If an unemployment rate for a household's MSA was unavailable or if the household was outside of a MSA, it was assigned its state's average unemployment rate for $1995 .^{7}$ Dummy variables for eight of the nine census regions were included to capture any geographic variation in anxiety not captured by any of the other series.

To test the importance of news reports of layoffs on households' anxiety, I included a variable from the Michigan survey that asks if the respondent has heard unfavorable news on layoffs. The survey asks the question:

During the last few months, have you heard of any favorable or unfavorable changes in business conditions? What did you hear? (Surveys of Consumers, December 1996)

\footnotetext{
${ }^{7}$ The unemployment rates used in the estimation are the published BLS estimates--see Employment and Earnings, January 1996.
} 
If the respondent mentions that he heard news of plant, store, or government facilities closings as well as general news of layoffs, then a dummy variable (BADNEWS) was set equal to 1 ; otherwise it was zero.

To test if anxious households are more pessimistic about the overall state of the economy, I included responses to two other Michigan survey questions. The first asks the household about expected business conditions over the coming year. If the household responded that they expect business conditions to be bad, then a dummy variable (EXP_BUSINESS) was set equal to 1 and zero otherwise. Similarly, if a household responded that they felt current business conditions were bad, a dummy variable (CUR_BUSINESS) was set equal to 1 and zero otherwise.

The final two variables included in the model are SAVINGS and CREDIT, which are intended to capture the impact that job insecurity might have on real economic activity. The Michigan survey question on savings asks:

If there were a major purchase that you wanted to make, do you think that now is a time when it would be O.K. to use some of your savings or is now a time when you would be especially reluctant to use some of your savings? (Survey of Consumers, December 1996)

The question related to the use of credit is worded similarly; however, it refers to taking on new debt. The dummy variables were set equal to 1 (SAVINGS=1 or CREDIT=1) if the respondent indicated that he was especially reluctant to use savings now or take on new debt and zero otherwise.

Of course, the Michigan survey does not record outcomes. Thus, there is no way to determine if a household that states that it is reluctant to take on debt actually reduces its debt or shaves its rate of increase. However, a significant relationship between anxiety and the SAVINGS or CREDIT variables might suggest that anxiety could affect real economic activity. An alternative might be that anxious households behave no differently than households that are unconcerned about job security.

The sample means for the Michigan data are also listed in table 3 based upon a household's classification as anxious $(\mathrm{ANX}=1)$ or not anxious $(\mathrm{ANX}=0)$. Looking down the 
table, only a few differences are apparent between the two groups. Anxious households have lower average incomes and fewer are home owners; however, relatively more anxious households reported that their homes had not increased in value over the past year. A somewhat larger proportion of anxious households are black, Hispanic or Asian, but more striking is the lower average educational attainment of anxious households. The percentage of anxious households that did not complete high school is more than double the percentage for households that were not anxious.

A greater proportion of anxious household reported that they had heard unfavorable news of layoffs, and anxious households appeared to be quite noticeably more negative about overall economic conditions. Almost half of anxious, employed households viewed current and expected business conditions as bad versus about $1 / 4$ of households that were not anxious. Finally, a slightly greater proportion of anxious households are reluctant to use savings or credit to finance a major purchase.

To examine the impact of these various factors on anxiety, I estimated a logit model with a maximum likelihood procedure--the estimated coefficients are shown in table $4 .{ }^{8}$ As seen in the table, family income is highly significant--the higher the household's income, the less likely it is anxious. Education also is important. Households in which the respondent did not graduate from high school were much more likely to be anxious than those in which the respondent was a college graduate. Black and Asian households were significantly more likely to be anxious relative to white households. Marital status, age, and sex of the respondent, and the presence of children had no impact on the probability that the household was anxious.

The coefficient on the local unemployment rate (UNR) was not significant. I employed a number of alternative specifications with the local unemployment rate which included using the difference between the local and national unemployment rate as a regressor. However, in none of these alternative specifications was the coefficient on the

\footnotetext{
${ }^{8}$ Once again, the coefficients can be interpreted as relative to a college educated, prime age (25 to 54), married, white male with children who is a home owner and lives in the suburbs of a metropolitan area in the South Atlantic census region.
} 
local unemployment rate significant.

Estimated coefficients on several of the regional dummy variables were significant. Living in census region 1 (New England), region 2 (New York, New Jersey, and Pennsylvania), region 7 (Arkansas, Louisiana, Oklahoma, and Texas), or region 9 (California, Washington, Oregon, Alaska, or Hawaii), significantly raised the likelihood of being anxious relative to someone living in the southern Atlantic states. It appears that the regional dummies captured some local labor market effects. When they were excluded from the model, the coefficient on the unemployment rate was positive and significant. In addition, the regional dummies may be capturing regional differences in the mix of employment by occupation and industry as well as other factors.

The coefficient on BADNEWS was statistically significant at the 10 percent level, which suggests that households that have heard unfavorable news about layoffs or plant closings are more likely to be anxious. Anxiety and negative views of current and expected business conditions were highly correlated--the coefficients on EXP_BUSINESS and CUR_BUSINESS are both positive and significant. The results also indicate an interesting view on the use of savings or credit to finance major purchases. The coefficient on SAVINGS was positive but insignificant--indicating little relationship between a negative response on using savings and job anxiety. One possible explanation is that many households simply do not have any savings. ${ }^{9}$ In the Michigan survey savings questions, households that state that they have no savings are recorded under a different response from those that say that they would not use savings. However, it is possible that some households without savings replied hypothetically that they would not use savings to finance a purchase. ${ }^{10}$

The coefficient on CREDIT was positive and significant, so that households that responded that they did not want to take on new debt were significantly more likely to be

\footnotetext{
${ }^{9}$ Data from the 1995 Survey of Consumer Finances conducted by the Federal Reserve Board found that only about 55 percent of families reported having saved in 1995. See Kennickell, StarrMcCluer, and Sundén (1997).

${ }^{10} \mathrm{~A}$ more rigorous approach to the question would first ask if the household held savings and then ask is they would be willing to use it.
} 
anxious. Thus, job anxiety might constrain spending behavior, although this cannot be proved with the data in hand.

Table 4 also shows the results of estimating the model using the full Michigan sample. Combining employed and unemployed/NILF households had little impact on the overall results. All of the other variables that were significant using only employed households remained significant in the full sample.

\subsection{Another Look at Business Conditions, Savings, and Credit}

In order to get a better understanding of the impact of anxiety on households' views on current and expected business conditions, I estimated the model with EXP_BUSINESS and CUR_BUSINESS as the dependant variables. The results of these estimations are shown in table 5 .

The first column of table 5 shows the anxiety model (ANX as the dependent variable) re-estimated excluding EXP_BUSINESS, CUR_BUSINESS along with SAVINGS and CREDIT. Excluding these variables doesn't change the model's results by much. The coefficients on NOVALUE and FEMALE are now significant, suggesting that households that report that their house did not increase in value are more likely to be anxious as were households in which the respondent was female.

The next set of estimates show the results of estimating the model with ANX as an explanatory variable. As seen in the table, the coefficient on ANX is positive and significant at the 5 percent level in both the of EXP_BUSINESS and CUR_BUSINESS models. Other factors that increased the likelihood of having negative views on current or expected business were lack of home appreciation and being less than age 25 , female, black, or Asian. To a lesser extent, hearing bad news about layoffs or living outside of an MSA also increased the likelihood of having negative views. Significant factors that lessened the likelihood of having negative views about the economy were being a renter and being unmarried.

Table 6 looks at the role of anxiety in the desire to use savings or credit to finance major purchases. In the model with SAVINGS as the dependent variable, the coefficient on anxiety (ANX) is positive by insignificantly different from zero. However, the coefficient on MATURE is significant and negative--indicating that households in which the respondent was over age 65 were less likely to say that they did not want to use savings. This certainly 
seems reasonable given that individuals in this age group have lower saving rates (Browning and Lusardi, 1996). However, households in which the respondent had a high school diploma and/or some college were more likely to state that they did not favor using savings relative to a college educated household. Geography did not play an important role in responses to the savings question, but hearing news about layoffs had a small positive influence.

In the model with CREDIT as the dependent variable, the coefficient on ANX is positive and significant, suggesting that anxious households were more likely to say that they were unwilling to take on debt to finance expenditures. In addition, households in which the respondent was over age 65 were more likely to not want more debt. Higher income, being single, and not owning a home all lowered the likelihood of responding that one did not want to take on more debt.

\subsection{Anxiety and the Probability of Being Employed}

Earlier, the probability of employment was estimated for each household (PROBE). It is possible that this probability might be helpful in explaining worker anxiety. Households that face a lower probability of employment (a higher probability of unemployment/NILF status) might be more anxious. To examine this possibility, I included the estimated probability of employment for each household as an explanatory variable in the logit model as PROBE. The results are shown in table 7.

Column 1 of table 7 shows the anxiety model estimated with PROBE as an explanatory variable. In the specification, the coefficient on PROBE is negative but insignificant. However, recall that family income (INCOME) was a key determinant of PROBE and it is likely that the two variables are good proxies for each other. The coefficient on INCOME is lower when PROBE is included, although it remained significant at the 10 percent level. In column 3, when INCOME was omitted from the model, the coefficient on PROBE became highly significant. Thus as one might expect, the higher the probability that a household is currently employed, the less likely it will be anxious. However, one must be careful about making inferences in the model shown in table 7. PROBE is a generated regressor in that it was created using data from both the CPS and Michigan surveys. As a result, the coefficient estimates are inefficient--the standard error 
of the coefficient on PROBE is too large (Pagan 1984, 1986).${ }^{11}$ However, since the standard error of PROBE is overstated, the statistical significance of the coefficient on PROBE would not be altered by use of the true (smaller) standard error.

\subsection{Has Anxiety Grown Over Time?}

Has worker anxiety grown in recent years? After all, corporate downsizing, mergers, and reorganizations have been with us for some time, and it is possible only our perception of job anxiety has changed. Nevertheless, it is difficult to shake the feeling that they $1990 \mathrm{~s}$ might be different as expressed by Paul Krugman:

"The success of what could be called 'the intimidation economy' depends on workers worrying more about security than wages. Being nice to the rich hasn't made much difference to the American economy, but being beastly to the poor does seem to increase efficiency. ${ }^{\prime 2}$

To examine worker anxiety over time, I re-estimated the logit anxiety model with Michigan survey data from July through December 1988 and compared the results to those obtained with the 1995 data. I chose 1988 largely because the overall macro economy resembled that of 1995 in many respects. In this way, I attempted to control for at least some aggregate factors that might affect sentiment. For example, the unemployment rate averaged 5.5 percent in 1988--similar to the 5.6 percent average in 1995. Also, in both years, the unemployment rate was declining and nonfarm payroll employment climbed about 3-1/4 percent. However, average annual real nonfarm hourly compensation edged down in 1988 while it rose a bit in 1995. Another difference between the two years is that in 1988, the stock market rose but remained below its pre-October 1987 level. In 1995, the stock market surged to record highs.

The six months of data in 1988 comprised 3,010 observations. Of these 271 observations were deleted because of incomplete information, which left a total of 2,739

\footnotetext{
11 The inefficiency arises from the use of variables in the first stage (CPS) logit estimation that were not used in the logit model estimates shown in table 7 .

12 "Inflation Could Soon Emerge from its Deep Sleep," New York Times, July 22, 1997.
} 
observations. Only questions 1 through 5 (see appendix A), which were used to identify anxious households in the 1995 data, were available in 1988 dataset. These questions revealed 14.7 percent of all households were anxious in 1988 compared to 26.6 percent in 1995 (based only on questions 1 through 5 in appendix A).

I re-estimated the model shown in table 4 with the 1988 data; however, some changes to the specification were necessary. Since the 1988 data did not contain information on home ownership or home value or whether the respondent lived in an urban or suburban area, these variables were excluded. I also excluded the business conditions variables along with SAVINGS and CREDIT. The logit model estimated with the 1988 data is shown in table 8. For comparison purposes, the model estimated with 1995 data is also shown.

As seen in the table, there are some differences between the estimated coefficients of the two models--particularly race and education. In the 1995 data, being a black or Asian household significantly increased the likelihood of being anxious relative to white households. However, race had little effect on anxiety in the 1988 model. Conversely, in the 1988 data all of the education variables are significant, suggesting that those with less than a college degree were significantly more likely to be anxious. In the 1995 data, only those lacking a high school diploma were significantly more likely to be anxious relative to those with a college degree.

The variable BADNEWS is positive and significant in both models with a coefficient of comparable magnitude in each. Thus, it does not appear that the impact of news reports on household anxiety changed much from 1988 to 1995 . However, as one might expect, the impact of one's geographic location on anxiety did change. In 1988, households in Census regions 7 and 8 were significantly more likely to be anxious. These regions include Louisiana, Texas, and Colorado--states that were adversely affected by the steep decline in oil prices in 1986. In 1995, anxious households were more likely to be found in regions 1,2 , and 9, which include New England, New York, and California--states that were hit hard by the 1990 recession and defense cutbacks.

If job anxiety has grown over time, then one would expect mean anxiety to be higher in 1995 than in 1988. At first blush, this would certainly seem the case. The percent of anxious households was about 80 percent higher in 1995 than in 1988 . To examine the issue 


\begin{tabular}{||lcc||}
\hline \hline \multicolumn{1}{|c|}{ ESTIMATED PROBABILITY OF ANXIETY FROM 1988 AND 1995 DATASETS } \\
& $\underline{1988 \text { Model }}$ & $\underline{1995 \text { Model }}$ \\
Mean & .15 & .27 \\
Standard deviation & .08 & .13 \\
Minimum Observation & .03 & .06 \\
Maximum Observation & .72 & .79 \\
Number of Observations & 2,739 & 2,732 \\
\hline
\end{tabular}

further, I compared the estimated probabilities of anxiety from the model estimated using 1988 and 1995 data. Some summary statistics from the two distributions are shown above.

Since tests indicated that the variances of the two distributions were not the same, I tested the equality of the mean probabilities using the Wilcoxon nonparametric approach. ${ }^{13}$ The test rejected the equality of the means at the 1 percent level--supporting the view that worker anxiety has indeed grown.

\section{Summary and Conclusions}

This paper has used individual responses to the Michigan survey to identify households with a concern over job security and has attempted to identify factors that might be driving this angst. It found that a little more than a quarter of households in 1995 revealed concern about job security. Although this proportion doesn't match the magnitudes of some opinion polls, it does suggest fairly widespread concern over job security.

The results suggest that less educated households (those lacking a high school diploma) were significantly more likely to be concerned about job loss. In addition, households in which the respondent was black or Asian were also more likely to be anxious relative to households in which the respondent was white. Also important in determining job anxiety were geographic factors, which likely reflect local labor market conditions in addition to geographic differences in the mix of employment by industry or occupation.

${ }^{13}$ See Mood, Graybill, and Boes (1974). 
The results also indicated that hearing news about layoffs or plant closings increased the likelihood that an employed household was anxious. Although media reports might not be the prime drivers of job insecurity, they may exacerbate such concerns. Anxious households also were more likely to be pessimistic about the overall economic environment, although the relationship was far from certain. This leaves room for the possibility that households could report generally favorable views about the overall economy, yet harbor significant concerns about their own job security. The results also suggested that anxious, employed households might be more reluctant to take on more debt than employed households that were not anxious. However, job anxiety did not appear to have any impact on households' views on using savings to finance major purchases. Finally, households that faced a higher probability of unemployment or NILF status were more likely to be anxious.

In order to examine if anxiety has increased in recent years, survey results from 1988 were compared to those from 1995. The results suggest that job anxiety was higher in 1995 than in 1988 with race, education, and geography again playing dominant roles in identifying anxious households. 


\section{APPENDIX A}

\section{DEFINITION OF ANXIETY USING MICHIGAN SURVEY DATA}

This appendix lists the questions and responses that were used to identify households as "anxious." The questions in the survey often ask the respondent to indicate if she is better off/worse off or if now is a good/bad time to buy and her reasons for saying so. I use the reasons given to identify anxious households. Note that a negative response does not make the household "anxious." For example, in response to question 1 (below), a household might be worse off financially because of a lower investment return this year with no mention of job security. This household would not be labeled "anxious."

\section{Question \#1:}

We are interested in how people are getting along financially these days. Would you say that you (and your family living there) are better off or worse off financially than you were a year ago?

\section{Follow up:}

If worse off, why do you say so?

Anxious response (coded by interviewer):

"Less security (job less secure); lower standard of living."

\section{Question \#2:}

Generally speaking, do you think now is a good time or a bad time to buy a house?

\section{Follow up:}

If a bad time, why do you say so?

Anxious response (coded by interviewer):

"People should save money; uncertainty of future; bad times ahead; employment too uncertain."

\section{Question \#3:}

What about selling a house--generally speaking, do you think now is a good time or a bad time to sell a house? (Not available in the 1988 survey)

Follow up:

If a bad time, why do you say so?

Anxious response (coded by interviewer):

"People should save money; uncertainty of future; bad times ahead; employment too uncertain."

\section{Question \#4:}

About the big things people buy for their homes -- such as furniture, a refrigerator, stove, television, and things like that. Generally speaking, do you think now is a good or a bad time for people to buy major household items?

Follow up: 
If a bad time, why do you say so?

Anxious response (coded by interviewer):

"People should save money; uncertainty of future; bad times ahead; employment too uncertain."

Question \#5:

Speaking now of the automobile market -- do you think the next 12 months or so will be a good time or a bad time to buy a car?

\section{Follow up:}

If a bad time, why do you say so?

Anxious response (coded by interviewer):

"People should save money; uncertainty of future; bad times ahead; employment too uncertain."

\section{Question \#6:}

How about pickups, vans, and jeep-type vehicles, do you think the next 12 months or so will be a good or a bad time to buy a pickup, van, or jeep-type vehicle?

Follow up:

If a bad time, why do you say so?

Anxious response (coded by interviewer):

"People should save money; uncertainty of future; bad times ahead; employment too uncertain." 


\section{REFERENCES}

Browning, M. and A. Lusardi (1996). "Household Saving: Micro Theories and Micro Facts." Journal of Economic Literature, vol. 34 (December), pp. 1797-1855.

Clark, K. B. and L. H. Summers (1982). "The Dynamics of Youth Unemployment," in R. Freedman and D. Wise, ed., The Youth Labor Market Problem: Its Nature, Causes and Consequences (University of Chicago Press for the National Bureau of Economic Research), pp. 199-234.

Dominitz, J. and C. F. Manski (1996). "Perceptions of Economic Insecurity: Evidence from the Survey of Economic Expectations, Forthcoming, Public Opinion Quarterly.

Flinn, C. J. and J. J. Heckman (1982). "Models for the Analysis of Labor Force Dynamics." Advances in Econometrics, pp. 35-95.

Gönül, F. (1992). "New Evidence on Whether Unemployment and Out of the Labor Force are Distinct States," Journal of Human Resources, vol. 27 (Spring), pp. 329-361.

Kennicke11, A. B., M. Starr-McCluer, and A. E. Sundén (1997). "Family Finances in the U.S.: Recent Evidence from the Survey of Consumer Finances." Federal Reserve Bulletin, vol. 83 (January), pp. 1-24.

Maddala, G. S. (1983). Limited Dependent and Qualitative Variables in Economics. Cambridge, England: Cambridge University Press.

Mood, A. M., F. A. Graybill, and D. C. Boes (1974). Introduction to the Theory of Statistics. New York: McGraw-Hill Book Company.

Press, S. J. and S. Wilson (1978). "Choosing Between Logistic Regression and Discriminant Analysis," Journal of the American Statistical Association, vol. 73 (December), pp. 699-705.

Survey Research Center at the University of Michigan. Surveys of Consumers. Ann Arbor, Michigan: SRC, December 1996.

U.S. Department of Labor. Employment and Earnings. Washington, DC: BLS, January 1997. 
Table 1

\section{VARIABLE DEFINITIONS FOR THE CPS LOGIT REGRESSION \\ (Unweighted data from March 1995 CPS)}

\begin{tabular}{|c|c|c|}
\hline Variable Definitions and Sample Means & Employed & $\begin{array}{l}\text { Unemployed/ } \\
\text { NILF }\end{array}$ \\
\hline $\begin{array}{l}\text { INCOME = Total family income. } \\
\text { standard error }\end{array}$ & $\begin{array}{c}\$ 47,192 \\
(\$ 34,197)\end{array}$ & $\begin{array}{l}\$ 18,903 \\
(\$ 19,233)\end{array}$ \\
\hline $\begin{array}{l}\text { UNR = } 1995 \text { MSA or state unemployment rate (percent). } \\
\text { standard error }\end{array}$ & $\begin{array}{c}5.26 \\
(1.67)\end{array}$ & $\begin{array}{c}5.47 \\
(1.74)\end{array}$ \\
\hline $\begin{array}{l}\text { NOHOME = Dummy variable equal to } 1 \text { if the home is not owned (or } \\
\text { being purchased) and zero otherwise. }\end{array}$ & 33.5 & 38.1 \\
\hline $\begin{array}{l}\text { NOKIDS }=\text { Dummy variable equal to } 1 \text { if the household has no members } \\
\text { less than } 18 \text { years old and zero otherwise. }\end{array}$ & 54 & 84.3 \\
\hline $\begin{array}{l}\text { CITY = Dummy variable equal to } 1 \text { if the household is in a center city and } \\
\text { zero otherwise. }\end{array}$ & 22.8 & 27 \\
\hline $\begin{array}{l}\text { NOMSA = Dummy variable equal to } 1 \text { if the household is not in a } \\
\text { MSA and zero otherwise. }\end{array}$ & 22.8 & 27.5 \\
\hline $\begin{array}{l}\text { YOUTH = Dummy variable equal to } 1 \text { if the household respondent is } \\
\text { at least age } 21 \text { but less than age } 25 \text { and zero otherwise. }\end{array}$ & 4.8 & 2.5 \\
\hline $\begin{array}{l}\text { OLDER }=\text { Dummy variable equal to } 1 \text { if the household respondent is at } \\
\text { least age } 55 \text { but less than age } 65 \text { and zero otherwise. }\end{array}$ & 12.8 & 12 \\
\hline $\begin{array}{l}\text { MATURE = Dummy variable equal to } 1 \text { if the household respondent is age } \\
65 \text { or older and zero otherwise. }\end{array}$ & 7.3 & 64 \\
\hline $\begin{array}{l}\text { BLACK = Dummy variable equal to } 1 \text { if the household respondent is of } \\
\text { African decent and not of Hispanic origin; zero otherwise. }\end{array}$ & 8.8 & 11.1 \\
\hline $\begin{array}{l}\text { HISP = Dummy variable equal to } 1 \text { if the household respondent is of } \\
\text { Hispanic origin and zero otherwise. }\end{array}$ & 11.1 & 9.5 \\
\hline $\begin{array}{l}\text { INDIAN = Dummy variable equal to } 1 \text { if the household respondent is a } \\
\text { Native American and zero otherwise. }\end{array}$ & 0.8 & 1 \\
\hline $\begin{array}{l}\text { ASIAN = Dummy variable equal to } 1 \text { if the household respondent is of } \\
\text { Asian decent and zero otherwise. }\end{array}$ & 2.8 & 1.6 \\
\hline $\begin{array}{l}\text { OTHER = Dummy variable equal to } 1 \text { if the household respondent is } \\
\text { neither white, black, Hispanic, Indian, or Asian and zero otherwise. }\end{array}$ & 0.4 & .2 \\
\hline $\begin{array}{l}\text { NO_HS = Dummy variable equal to } 1 \text { if the household respondent never } \\
\text { completed high school and zero otherwise. }\end{array}$ & 13.6 & 37.4 \\
\hline $\begin{array}{l}\text { HIGH_SCHOOL = A dummy variable equal to } 1 \text { if the respondent } \\
\text { completed high school and zero otherwise. }\end{array}$ & 31.4 & 32.3 \\
\hline $\begin{array}{l}\text { SOME_COLL }=\text { A dummy variable equal to } 1 \text { if the household respondent } \\
\text { attended college but did not graduate and zero otherwise. }\end{array}$ & 19.3 & 14.4 \\
\hline
\end{tabular}

The table is continued on the following page. 
Table 1 (continued)

VARIABLE DEFINITIONS FOR THE CPS LOGIT REGRESSION

(Unweighted data from March 1995 CPS)

\begin{tabular}{|c|c|c|}
\hline Variable Definitions and Sample Means & Employed & Unemployed \\
\hline $\begin{array}{l}\text { NOMARRY = A dummy variable equal to } 1 \text { if the household respondent } \\
\text { has never been married and zero otherwise. }\end{array}$ & 15.5 & 13.3 \\
\hline $\begin{array}{l}\text { DIV_SEP = A dummy variable equal to } 1 \text { if the household respondent is } \\
\text { widowed, divorced, or separated and zero otherwise. }\end{array}$ & 20.9 & 49.4 \\
\hline $\begin{array}{l}\text { FEMALE = A dummy variable equal to } 1 \text { if the respondent is a female } \\
\text { and zero otherwise. }\end{array}$ & 31.6 & 52.6 \\
\hline $\begin{array}{l}\text { CENS1 = Dummy variable equal to } 1 \text { if the household lives in the New } \\
\text { England census region and zero otherwise. }\end{array}$ & 8.3 & 8.7 \\
\hline $\begin{array}{l}\text { CENS2 = Dummy variable equal to } 1 \text { if the household lives in the Middle } \\
\text { Atlantic census region and zero otherwise. }\end{array}$ & 15 & 17.8 \\
\hline $\begin{array}{l}\text { CENS3 = Dummy variable equal to } 1 \text { if the household lives in the East } \\
\text { North Central census region and zero otherwise. }\end{array}$ & 15.1 & 14.7 \\
\hline $\begin{array}{l}\text { CENS4 }=\text { Dummy variable equal to } 1 \text { if the household lives in the West } \\
\text { North Central census region and zero otherwise. }\end{array}$ & 8.4 & 7.6 \\
\hline $\begin{array}{l}\text { CENS6 = Dummy variable equal to } 1 \text { if the household lives in the East } \\
\text { South Central census region and zero otherwise. }\end{array}$ & 4.5 & 5.2 \\
\hline $\begin{array}{l}\text { CENS7 = Dummy variable equal to } 1 \text { if the household lives in the West } \\
\text { South Central census region and zero otherwise. }\end{array}$ & 8.8 & 7.9 \\
\hline $\begin{array}{l}\text { CENS8 = Dummy variable equal to } 1 \text { if the household lives in the } \\
\text { Mountain census region and zero otherwise. }\end{array}$ & 9.9 & 8.8 \\
\hline $\begin{array}{l}\text { CENS9 = Dummy variable equal to } 1 \text { if the household lives in the Pacific } \\
\text { Census region and zero otherwise. }\end{array}$ & 12.5 & 11.2 \\
\hline Number of observations (households) & 41,221 & 14,595 \\
\hline
\end{tabular}


Table 2

LOGIT REGRESSION FOR PROBABILITY OF EMPLOYMENT USING MARCH 1995 CPS DATA

Dependent variable equals 1 if the household contains at least 1 employed person age 21 or more, zero otherwise. Estimated coefficients

Standard error

\begin{tabular}{|c|c|c|}
\hline INTERCEPT & $-11.3292 * *$ & .2292 \\
\hline $\ln (\mathrm{INCOME})$ & $1.4167 * *$ & .0205 \\
\hline UNR & $-.0496 * *$ & .0100 \\
\hline NOHOME & $-.2549 * *$ & .0354 \\
\hline NOKIDS & -.0416 & .0386 \\
\hline CITY & $-.1913 * *$ & .0361 \\
\hline NOMSA & -.0117 & .0360 \\
\hline YOUTH & $.4269 * *$ & .0713 \\
\hline OLDER & $-1.4402 * *$ & .0452 \\
\hline MATURE & $-3.5556 * *$ & .0424 \\
\hline BLACK & $.1207 * *$ & .0492 \\
\hline HISP & $.2945^{* *}$ & .0517 \\
\hline INDIAN & $-.3830 * *$ & .1316 \\
\hline ASIAN & $.3158 * *$ & .1023 \\
\hline OTHER & .4277 & .2794 \\
\hline NO_HS & $-.0906 * *$ & .0444 \\
\hline HIGH_SCHOOL & .0095 & .0395 \\
\hline SOME_COLL & .0153 & .0454 \\
\hline NOMARRY & -.0443 & .0486 \\
\hline DIV_SEP & -.0425 & .0384 \\
\hline FEMALE & $-.1157 * *$ & .0339 \\
\hline CENS1 & -.0838 & .0597 \\
\hline CENS2 & $-.1647 * *$ & .0513 \\
\hline CENS3 & -.0186 & .0495 \\
\hline CENS4 & $.2509 * *$ & .0629 \\
\hline CENS6 & .0545 & .0716 \\
\hline CENS7 & $.3287^{* *}$ & .0599 \\
\hline CENS8 & .0326 & .0571 \\
\hline CENS9 & -.0846 & .0572 \\
\hline
\end{tabular}

Memo:

Likelihood ratio test: 30017.7 with 28 degrees of freedom and $\mathrm{p}=.0001$.

*** Indicates statistically significant at the 5 percent level using Wald test which uses the chi-squared distribution. 
Table 3

VARIABLE DEFINITIONS FOR THE MICHIGAN ANXIETY MODEL (Unweighted data from Michigan surveys, June-December 1995, excluding September)

\begin{tabular}{|c|c|c|}
\hline Variable definitions and sample means (employed households only) & $\begin{array}{l}\text { Anxious } \\
(\text { ANX }=1)\end{array}$ & $\begin{array}{l}\text { Not anxious } \\
\quad(\mathrm{ANX}=0)\end{array}$ \\
\hline $\begin{array}{l}\text { INCOME = Total family income. } \\
\text { standard error }\end{array}$ & $\begin{array}{l}\$ 45,186.2 \\
(\$ 38,768)\end{array}$ & $\begin{array}{l}\$ 54,291.1 \\
(\$ 48,719)\end{array}$ \\
\hline $\begin{array}{l}\text { UNR }=1995 \text { MSA or state unemployment rate (percent). } \\
\text { standard error }\end{array}$ & $\begin{array}{c}5.63 \\
(1.86)\end{array}$ & $\begin{array}{c}5.15 \\
(1.69)\end{array}$ \\
\hline $\begin{array}{l}\text { NOHOME = Dummy variable equal to } 1 \text { if the home is not owned (or } \\
\text { being purchased) and zero otherwise. }\end{array}$ & 36.3 & 29.2 \\
\hline $\begin{array}{l}\text { NOVALUE = Dummy variable equal to } 1 \text { if the respondents indicated that } \\
\text { their homes had not increased in value over the past year and zero } \\
\text { otherwise. }\end{array}$ & 73.3 & 62.3 \\
\hline $\begin{array}{l}\text { NOKIDS }=\text { Dummy variable equal to } 1 \text { if the household has no members } \\
\text { less than } 18 \text { years old and zero otherwise. }\end{array}$ & 52.8 & 55.1 \\
\hline $\begin{array}{l}\text { CITY = Dummy variable equal to } 1 \text { if the household is in a center city and } \\
\text { zero otherwise. }\end{array}$ & 38.4 & 36.8 \\
\hline $\begin{array}{l}\text { NOMSA = Dummy variable equal to } 1 \text { if the household is not in a } \\
\text { MSA and zero otherwise. }\end{array}$ & 23.8 & 22.3 \\
\hline $\begin{array}{l}\text { YOUTH }=\text { Dummy variable equal to } 1 \text { if the household respondent is } \\
\text { at least age } 21 \text { but less than age } 25 \text { and zero otherwise. }\end{array}$ & 10.4 & 9.8 \\
\hline $\begin{array}{l}\text { OLDER }=\text { Dummy variable equal to } 1 \text { if the household respondent is at } \\
\text { least age } 55 \text { but less than age } 65 \text { and zero otherwise. }\end{array}$ & 12.9 & 11.5 \\
\hline $\begin{array}{l}\text { MATURE }=\text { Dummy variable equal to } 1 \text { if the household respondent is age } \\
65 \text { or older and zero otherwise. }\end{array}$ & 1.8 & 2.7 \\
\hline $\begin{array}{l}\text { BLACK = Dummy variable equal to } 1 \text { if the household respondent is of African } \\
\text { decent and not of Hispanic origin; zero otherwise. }\end{array}$ & 11.8 & 6.7 \\
\hline $\begin{array}{l}\text { HISP = Dummy variable equal to } 1 \text { if the household respondent is of } \\
\text { Hispanic origin and zero otherwise. }\end{array}$ & 10.1 & 5.4 \\
\hline $\begin{array}{l}\text { INDIAN = Dummy variable equal to } 1 \text { if the household respondent is a } \\
\text { Native American and zero otherwise. }\end{array}$ & 1.5 & 1.0 \\
\hline $\begin{array}{l}\text { ASIAN = Dummy variable equal to } 1 \text { if the household respondent is of } \\
\text { Asian decent and zero otherwise. }\end{array}$ & 4.1 & 1.6 \\
\hline $\begin{array}{l}\text { OTHER = Dummy variable equal to } 1 \text { if the household respondent is neither white, } \\
\text { black, Hispanic, Indian, or Asian and zero otherwise. }\end{array}$ & 0.7 & 1.3 \\
\hline $\begin{array}{l}\text { NO_HS }=\text { Dummy variable equal to } 1 \text { if the household respondent never } \\
\text { completed high school and zero otherwise. }\end{array}$ & 10.8 & 5.0 \\
\hline $\begin{array}{l}\text { HIGH_SCHOOL }=\text { A dummy variable equal to } 1 \text { if the respondent } \\
\text { completed high school and zero otherwise. }\end{array}$ & 33.1 & 28.4 \\
\hline $\begin{array}{l}\text { SOME_COLL }=\text { A dummy variable equal to } 1 \text { if the household respondent } \\
\text { attended college but did not graduate and zero otherwise. }\end{array}$ & 42.7 & 51.1 \\
\hline $\begin{array}{l}\text { NOMARRY = A dummy variable equal to } 1 \text { if the household respondent } \\
\text { has never been married and zero otherwise. }\end{array}$ & 20.2 & 18.8 \\
\hline
\end{tabular}


Table 3 (continued)

VARIABLE DEFINITIONS FOR THE MICHIGAN ANXIETY MODEL (Unweighted data from Michigan surveys, June-December 1995, excluding September)

\begin{tabular}{|c|c|c|}
\hline Variable definitions and sample means (employed households only) & $\begin{array}{l}\text { Anxious } \\
(\mathrm{ANX}=1)\end{array}$ & $\begin{array}{r}\text { Not anxious } \\
(\mathrm{ANX}=0)\end{array}$ \\
\hline $\begin{array}{l}\text { DIV_SEP = A dummy variable equal to } 1 \text { if the household respondent is } \\
\text { widowed, divorced, or separated and zero otherwise. }\end{array}$ & 21.0 & 16.8 \\
\hline $\begin{array}{l}\text { FEMALE = A dummy variable equal to } 1 \text { if the respondent is a female } \\
\text { and zero otherwise. }\end{array}$ & 56.3 & 48.0 \\
\hline $\begin{array}{l}\text { CENS1 = Dummy variable equal to } 1 \text { if the household lives in the New } \\
\text { England census region and zero otherwise. }\end{array}$ & 6.8 & 5.1 \\
\hline $\begin{array}{l}\text { CENS2 = Dummy variable equal to } 1 \text { if the household lives in the Middle } \\
\text { Atlantic census region and zero otherwise. }\end{array}$ & 18.7 & 12.7 \\
\hline $\begin{array}{l}\text { CENS3 = Dummy variable equal to } 1 \text { if the household lives in the East } \\
\text { North Central census region and zero otherwise. }\end{array}$ & 15.1 & 19.5 \\
\hline $\begin{array}{l}\text { CENS4 = Dummy variable equal to } 1 \text { if the household lives in the West } \\
\text { North Central census region and zero otherwise. }\end{array}$ & 5.1 & 8.7 \\
\hline $\begin{array}{l}\text { CENS6 = Dummy variable equal to } 1 \text { if the household lives in the East } \\
\text { South Central census region and zero otherwise. }\end{array}$ & 4.8 & 6.8 \\
\hline $\begin{array}{l}\text { CENS7 = Dummy variable equal to } 1 \text { if the household lives in the West } \\
\text { South Central census region and zero otherwise. }\end{array}$ & 10.8 & 9.3 \\
\hline $\begin{array}{l}\text { CENS8 = Dummy variable equal to } 1 \text { if the household lives in the } \\
\text { Mountain census region and zero otherwise. }\end{array}$ & 4.3 & 6.8 \\
\hline $\begin{array}{l}\text { CENS9 = Dummy variable equal to } 1 \text { if the household lives in the Pacific } \\
\text { census region and zero otherwise. }\end{array}$ & 20.7 & 12.4 \\
\hline $\begin{array}{l}\text { BADNEWS = Dummy variable equal to one if respondent reports hearing } \\
\text { unfavorable news about plant closings or layoffs and zero otherwise. }\end{array}$ & 19.2 & 12.8 \\
\hline $\begin{array}{l}\text { EXP_BUSINESS }=\text { A dummy variable equal to } 1 \text { if respondent expects } \\
\text { bad business conditions over the next twelve months and zero otherwise. }\end{array}$ & 46.4 & 26.2 \\
\hline $\begin{array}{l}\text { CUR_BUSINESS = A dummy variable equal to } 1 \text { if respondent feels that } \\
\text { current business conditions are bad and zero otherwise. }\end{array}$ & 45.9 & 26.5 \\
\hline $\begin{array}{l}\text { SAVINGS = A dummy variable equal to } 1 \text { if the respondent feels that now } \\
\text { is not a good time to use savings to finance major purchases and zero } \\
\text { otherwise. }\end{array}$ & 64.7 & 60.5 \\
\hline $\begin{array}{l}\text { CREDIT = A dummy variable equal to } 1 \text { if the respondent feels that now } \\
\text { is not a good time to use credit to finance major purchases and zero } \\
\text { otherwise. }\end{array}$ & 80.1 & 71.6 \\
\hline Number of employed households & 604 & 1,730 \\
\hline
\end{tabular}


Table 4

LOGIT REGRESSION FOR LIKELIHOOD OF ANXIETY ACROSS HOUSEHOLDS

(Unweighted Michigan data; June through December 1995, excluding September)

\begin{tabular}{|c|c|c|c|c|}
\hline \multicolumn{5}{|c|}{$\begin{array}{c}\text { Dependent variable equals } 1 \text { if the household is anxious } \\
\text { Employed Households }\end{array}$} \\
\hline & & Standard error & Estimated coefficients & Standard error \\
\hline Intercept & .5664 & 1.0224 & .1302 & .8915 \\
\hline $\ln (\mathrm{INCOME})$ & $-.2866^{\star \star}$ & .0867 & $-.2407 * \pi$ & .0744 \\
\hline UNR & .0165 & .0337 & .0355 & .0301 \\
\hline NOHOME & -.0821 & .1354 & -.0802 & .1230 \\
\hline NOVALUE & .1383 & .1277 & .1445 & .1164 \\
\hline NOKIDS & -.0481 & .1138 & -.0183 & .1109 \\
\hline CITY & 0.598 & .1197 & .0624 & .1092 \\
\hline NOMSA & .1719 & .1363 & .0671 & .1239 \\
\hline YOUTH & -.0156 & .1848 & .0189 & .1812 \\
\hline OLDER & .1160 & .1644 & .1276 & .1564 \\
\hline MATURE & .0751 & .3638 & .0364 & .1552 \\
\hline BLACK & $.5199 *$ & .1788 & $.5422^{* *}$ & .1640 \\
\hline HISP & .1449 & .2030 & .1535 & .1947 \\
\hline INDIAN & .3713 & .4452 & .5541 & .4147 \\
\hline ASIAN & $1.1816^{\star \star *}$ & .3045 & $1.1583^{\star \star *}$ & .2975 \\
\hline OTHER & -.7139 & .5847 & -.6965 & .4910 \\
\hline NO_HS & $.5250^{* *}$ & .2420 & $.5420^{* *}$ & .2080 \\
\hline HIGH_SCHOOL & .1382 & .1718 & .0741 & .1611 \\
\hline SOME_COLL & -.1625 & .1584 & -.1839 & .1501 \\
\hline NOMARRY & .0446 & .1564 & -.0308 & .1490 \\
\hline DIV_SEP & .1364 & .1391 & .0425 & .1219 \\
\hline CENS1 & $.6696^{* *}$ & .2400 & $.6324 * *$ & .2179 \\
\hline CENS2 & $.6896^{* *}$ & .1878 & $.4622^{* *}$ & .1663 \\
\hline CENS3 & .1983 & .1799 & -.0196 & .1618 \\
\hline CENS4 & -.0407 & .2470 & -.00489 & .2154 \\
\hline CENS6 & .0180 & .2545 & -.2614 & .2358 \\
\hline CENS7 & $.4591^{* *}$ & .2076 & $.3422^{*}$ & .1881 \\
\hline CENS8 & -.0547 & .2629 & -.1259 & .2321 \\
\hline
\end{tabular}

The table is continued on the following page. 
Table 4 (Continued)

LOGIT REGRESSION FOR LIKELIHOOD OF ANXIETY AMONGST HOUSEHOLDS

(Unweighted Michigan data; June through December 1995, excluding September)

\begin{tabular}{|c|c|c|c|c|}
\hline \multicolumn{5}{|c|}{ Dependent variable equals 1 if the household is anxious (see appendix $\mathrm{A}$ ) and zero otherwise. } \\
\hline & \multicolumn{2}{|c|}{ Employed Households } & \multicolumn{2}{|c|}{ All Households } \\
\hline & Estimated coefficients & Standard error & Estimated coefficients & Standard error \\
\hline CENS9 & $.8754^{* *}$ & .1956 & $.6663^{* *}$ & .1753 \\
\hline FEMALE & .1227 & .1041 & .0929 & .0958 \\
\hline BADNEWS & $0.2363^{*}$ & .1396 & $.2179^{*}$ & .1257 \\
\hline EXP_BUSINESS & $.4974 * *$ & .1161 & $.5713^{* *}$ & .1050 \\
\hline CUR_BUSINESS & $0.5194 *$ & .1174 & $.5231 * *$ & .1058 \\
\hline SAVINGS & .0523 & .1105 & .0532 & .0999 \\
\hline CREDIT & $.2716^{* *}$ & 0.1280 & $.3117^{* *}$ & .1200 \\
\hline \multicolumn{5}{|l|}{ Memo: } \\
\hline Sample size & 2,334 households & & 2,732 households & \\
\hline $\begin{array}{l}\text { Likelihood ratio test } \\
\qquad(\mathrm{df}=34)\end{array}$ & 256.079 & $\mathrm{p}=0.0001$ & 325.913 & $\mathrm{p}=0.0001$ \\
\hline
\end{tabular}

$\approx *$ Indicates significance at the 5 percent level using the Wald test with a chi-squared distribution.

* Indicates significance at the 10 percent level. 
Table 5

THE IMPACT OF JOB ANXIETY ON VIEWS OF CURRENT AND EXPECTED BUSINESS CONDITIONS OF EMPLOYED HOUSEHOLDS

(Unweighted Michigan data; June through December 1995, excluding September)

\begin{tabular}{|c|c|c|c|c|c|c|}
\hline \multirow[t]{2}{*}{ Dependent variable } & \multicolumn{2}{|r|}{ ANX } & \multicolumn{2}{|c|}{ EXP_BUSINESS } & \multicolumn{2}{|c|}{ CUR_BUSINESS } \\
\hline & Coefficient & Standard error & Coefficient & Standard error & Coefficient & Standard error \\
\hline Intercept & $1.7393^{\star}$ & .9901 & 1.4015 & .9524 & .0070 & .9571 \\
\hline ANX & & & $.7232 * * 6$ & .1055 & $.7359 * *$ & .1068 \\
\hline $\ln (\mathrm{INCOME})$ & $-.3564 * \star$ & .0849 & $-.2958^{\star *}$ & .0811 & $-.1685^{\star \star}$ & .0814 \\
\hline UNR & .0106 & .0332 & -.0161 & .0334 & -.0090 & .0335 \\
\hline NOHOME & -.1756 & .1325 & $-.3315^{\star \star *}$ & .1284 & $-.3673^{\star *}$ & .1306 \\
\hline NOVALUE & $.2499 \approx$ & .1247 & $.4998^{* \star}$ & .1175 & $.3773^{* \star}$ & .1174 \\
\hline NOKIDS & -.0707 & .1120 & -.0474 & .1070 & -.1661 & .1084 \\
\hline CITY & .0885 & .1176 & .1158 & .1125 & .1231 & .1118 \\
\hline NOMSA & .1982 & .1336 & $.2478^{\star}$ & .1279 & .0068 & .1331 \\
\hline YOUTH & .0349 & .1819 & $.3994^{\star \star}$ & .1714 & .0616 & .1770 \\
\hline OLDER & .2024 & .1612 & .2149 & .1541 & $.5815^{\star \star}$ & .1524 \\
\hline MATURE & .0244 & .3599 & -.2329 & .3430 & -.3426 & .3468 \\
\hline BLACK & $.6026^{\star *}$ & .1758 & $.3750^{\star *}$ & .1738 & $.4371^{* *}$ & .1751 \\
\hline HISP & .2266 & .1994 & $.5263^{\star \star *}$ & .1947 & $.3558^{\star}$ & .1981 \\
\hline INDIAN & .3257 & .4339 & .3602 & .4178 & -.7807 & .5198 \\
\hline ASIAN & $1.0542^{\star *}$ & .2992 & $-.6817^{*}$ & .3631 & $-.6988^{*}$ & .3695 \\
\hline OTHER & -.6619 & .5688 & -.0345 & .4634 & .5534 & .4348 \\
\hline NO_HS & $.6005^{\star \star *}$ & .2381 & .3339 & .2395 & $.4205^{\star}$ & .2413 \\
\hline HIGH_SCHOOL & .2316 & .1683 & $.4432^{* *}$ & .1672 & $.3958^{* *}$ & .1692 \\
\hline SOME_COLL & -.0682 & .1548 & $.3290^{* *}$ & .1542 & $4710^{\star * *}$ & .1542 \\
\hline NOMARRY & -.0243 & .1540 & $-.3650 * *$ & .1512 & -.0925 & .1515 \\
\hline DIV_SEP & .1403 & .1368 & .0361 & .1317 & .0811 & .1331 \\
\hline BADNEWS & $.4700^{\star *}$ & .1341 & $.7868^{\star \star}$ & .1284 & $1.2624^{* *}$ & .1284 \\
\hline FEMALE & $.1939^{*}$ & .1018 & $.2755^{\star *}$ & .0971 & $.2297 * *$ & .0978 \\
\hline
\end{tabular}

The table is continued on the following page. 
Table 5 (continued)

THE IMPACT OF JOB ANXIETY ON VIEWS OF CURRENT AND EXPECTED BUSINESS CONDITIONS OF EMPLOYED HOUSEHOLDS

(Unweighted Michigan data; June through December 1995, excluding September)

\begin{tabular}{lcccccc}
\hline \multirow{2}{*}{ Dependent variable } & \multicolumn{2}{c}{ ANX } & \multicolumn{3}{c}{ EXP_BUSINESS } & \multicolumn{2}{c}{ CUR_BUSINESS } \\
\cline { 2 - 7 } & Coefficient & Standard error & Coefficient & Standard error & Coefficient & Standard error \\
\hline CENS1 & $.6418^{* *}$ & .2369 & .1058 & .2259 & -.3088 & .2409 \\
CENS2 & $.7125^{* *}$ & .1843 & .0854 & .1739 & .0169 & .1772 \\
CENS3 & .1579 & .1772 & -.2617 & .1605 & -.0153 & .1590 \\
CENS4 & -.1235 & .2425 & $-.5284^{* *}$ & $.2197^{* *}$ & $-.4440^{* *}$ & .2220 \\
CENS6 & -.0804 & .2503 & -.1363 & .2188 & -.3706 & .2309 \\
CENS7 & $.4196^{* *}$ & .2035 & $-.5101^{* *}$ & .1986 & -.0806 & .1925 \\
CENS8 & -.0162 & .2588 & .1170 & .2189 & .1190 & .2226 \\
CENS9 & $.8737^{* *}$ & .1920 & -.1763 & .1860 & -.0935 & .1875 \\
$\begin{array}{l}\text { Memo: } \\
\text { Likelihood }\end{array}$ & & & & & & \\
$\quad$ ratio test & 183.348 & $\mathrm{p}=.0001$ & 241.708 & $\mathrm{p}=.0001$ & 269.358 & $\mathrm{p}=.0001$ \\
\hline
\end{tabular}

$* *$ Indicates significance at the 5 percent level using the Wald test with a chi-squared distribution.

* Indicates significance at the 10 percent level.

The sample size is 2,334 employed households. 
Table 6

THE IMPACT OF JOB ANXIETY ON THE DESIRE TO USE SAVINGS OR TAKE ON NEW DEBT TO FINANCE A MAJOR PURCHASE (EMPLOYED HOUSEHOLDS ONLY)

(Unweighted Michigan data; June through December 1995, excluding September)

\begin{tabular}{|c|c|c|c|c|c|c|}
\hline \multirow[t]{2}{*}{ Dependent variable } & \multicolumn{2}{|r|}{ ANX } & \multicolumn{2}{|c|}{ SAVINGS } & \multicolumn{2}{|c|}{ CREDIT } \\
\hline & Coefficient & Standard error & Coefficient & Standard error & Coefficient & Standard error \\
\hline Intercept & $1.7393^{\star}$ & 1.7393 & -.2287 & .8772 & $5.1959^{* *}$ & .9953 \\
\hline ANX & & & .1560 & .1039 & $.3587 * *$ & .1206 \\
\hline $\ln (\mathrm{INCOME})$ & $-.3564^{* \pi}$ & .0849 & .0159 & .0747 & $-.4344^{\star *}$ & .0847 \\
\hline UNR & .0106 & .0332 & -.0038 & .0310 & .0122 & .0359 \\
\hline NOHOME & -.1756 & .1325 & -.0465 & .1213 & $-.2651^{*}$ & .1357 \\
\hline NOVALUE & $.2499 \approx *$ & .1247 & $.3270^{* *}$ & .1069 & $.2002 *$ & .1189 \\
\hline NOKIDS & -.0707 & .1120 & -.1241 & .0983 & .0067 & .1092 \\
\hline CITY & .0885 & .1176 & -.0928 & .1018 & -.0200 & .1136 \\
\hline NOMSA & .1982 & .1336 & .0771 & .1192 & -.1800 & .1306 \\
\hline YOUTH & .0349 & .1819 & .2292 & .1652 & .1311 & .1815 \\
\hline OLDER & .2024 & .1612 & .1083 & .1450 & $.1096^{\star}$ & .1626 \\
\hline MATURE & .0244 & .3599 & $-.8986^{\star \star}$ & .2881 & $1.2118^{* *}$ & .4204 \\
\hline BLACK & $.6026^{* *}$ & .1758 & -.2608 & .1656 & .0810 & .1921 \\
\hline HISP & .2266 & .1994 & -.1892 & .1898 & -.2869 & .2127 \\
\hline INDIAN & .3257 & .4339 & .2400 & .4347 & -.2307 & .4569 \\
\hline ASIAN & $1.0542^{* *}$ & .2992 & .1925 & .3077 & .0325 & .3354 \\
\hline OTHER & -.6619 & .5688 & .2614 & .4147 & -.4183 & .4194 \\
\hline NO_HS & $.6005^{\star *}$ & .2381 & -.0355 & .2153 & -.0102 & .2469 \\
\hline HIGH_SCHOOL & .2316 & .1683 & $.3727^{\star *}$ & .1436 & .1298 & .1580 \\
\hline SOME_COLL & -.0682 & .1548 & $.5282^{\star *}$ & .1295 & .1778 & .1407 \\
\hline NOMARRY & -.0243 & .1540 & -.0518 & .1359 & $-.3762 * *$ & .1491 \\
\hline DIV_SEP & .1403 & .1368 & -.0026 & .1236 & -.1217 & .1409 \\
\hline BADNEWS & $.4700^{* *}$ & .1341 & $.2118^{*}$ & .1276 & .1458 & .1442 \\
\hline FEMALE & $.1939^{*}$ & .1018 & .0133 & .0893 & $.1804^{*}$ & .0993 \\
\hline
\end{tabular}

The table is continued on the following page. 
Table 6 (continued)

THE IMPACT OF JOB ANXIETY ON THE DESIRE TO USE SAVINGS OR TAKE ON NEW DEBT TO FINANCE A MAJOR PURCHASE (EMPLOYED HOUSEHOLDS ONLY)

(Unweighted Michigan data; June through December 1995, excluding September)

\begin{tabular}{lcccccc}
\hline \multirow{2}{*}{ Dependent. variable } & \multicolumn{2}{c}{ ANX } & \multicolumn{2}{c}{ SAVINGS } & \multicolumn{2}{c}{ CREDIT } \\
\cline { 2 - 7 } & Coefficients & Standard error & Coefficients & Standard error & Coefficients & Standard error \\
\hline CENS1 & $.6418^{* *}$ & .2369 & -.0985 & .2115 & .0837 & .2341 \\
CENS2 & $.7125^{* *}$ & .1843 & .1468 & .1650 & .1160 & .1801 \\
CENS3 & .1579 & .1772 & -.0594 & .1447 & -.0105 & .1568 \\
CENS4 & -.1235 & .2425 & -.0724 & .1890 & .3107 & .2143 \\
CENS6 & -.0804 & .2503 & -.0651 & .2020 & -.0456 & .2196 \\
CENS7 & $.4196^{* *}$ & .2035 & $.3004^{*}$ & .1817 & $.4408^{* *}$ & .2064 \\
CENS8 & -.0162 & .2588 & -.0640 & .2045 & .3115 & .2312 \\
CENS9 & $.8737^{* *}$ & .1920 & .0487 & .1727 & $.3631^{*}$ & .1950 \\
$\begin{array}{l}\text { Memo: } \\
\quad \text { Likelihood } \\
\text { ratio }\end{array}$ & 183.348 & $\mathrm{p}=.0001$ & 68.474 & $\mathrm{p}=.0001$ & 89.051 & $\mathrm{p}=.0001$ \\
\hline
\end{tabular}

$* *$ Indicates significance at the 5 percent level using the Wald test with a chi-squared distribution.

* Indicates significance at the 10 percent level.

The sample size is 2,334 employed households. 
Table 7

ANXIETY AND THE PROBABILITY OF EMPLOYMENT (ALL HOUSEHOLDS)

(Unweighted Michigan data; June through December 1995, excluding September)

\begin{tabular}{|c|c|c|c|c|c|c|}
\hline & \multicolumn{6}{|c|}{ Dependent variable equals 1 if the household is anxious (ANX) and zero otherwise. } \\
\hline & $\begin{array}{l}\text { Coefficient } \\
\text { (1) }\end{array}$ & $\begin{array}{l}\text { Standard error } \\
\text { (2) }\end{array}$ & $\begin{array}{l}\text { Coefficient } \\
\text { (3) }\end{array}$ & $\begin{array}{l}\text { Standard error } \\
\text { (4) }\end{array}$ & $\begin{array}{l}\text { Coefficient } \\
\text { (5) }\end{array}$ & $\begin{array}{l}\text { Standard error } \\
\text { (6) }\end{array}$ \\
\hline Intercept & .0382 & .9787 & $-1.400^{* *}$ & .5207 & -.6109 & .4977 \\
\hline PROBE & -.1582 & .6972 & $-1.1335 * *$ & .4157 & $-1.4754 * *$ & .4074 \\
\hline $\ln (\mathrm{INCOME})$ & $-.2176^{\star}$ & .1258 & & & & \\
\hline UNR & .0349 & .0302 & .0320 & .0302 & .0280 & .0294 \\
\hline NOHOME & -.0812 & .1230 & -.0507 & .1218 & -.1115 & .1190 \\
\hline NOVALUE & .1450 & .1164 & .1509 & .1162 & $.2666^{* *}$ & .1132 \\
\hline NOKIDS & -.0182 & .1109 & -.0188 & .1107 & -.0401 & .1084 \\
\hline CITY & .0598 & .1098 & .0499 & .1096 & .0726 & .1072 \\
\hline NOMA & .0674 & .1239 & .0812 & .1235 & .1292 & .1205 \\
\hline YOUTH & .0195 & .1812 & .0205 & .1811 & .0607 & .1779 \\
\hline OLDER & .1047 & .1862 & -.0311 & .1692 & .0250 & .1654 \\
\hline MATURE & -.0549 & .4315 & $-.5849^{*}$ & .3079 & $-.8070^{* *}$ & .3031 \\
\hline BLACK & $.5450^{\star \pi}$ & .1645 & $.5753^{\star \pi}$ & .1636 & $.6326^{* *}$ & .1607 \\
\hline HISP & .1589 & .1962 & .1985 & .1947 & .2837 & .1905 \\
\hline INDIAN & .5498 & .4153 & .5503 & .4157 & .5307 & .4015 \\
\hline ASIAN & $1.1606^{* *}$ & .2976 & $1.1799^{\star *}$ & .2969 & 1.0455 & .2904 \\
\hline OTHER & -.6941 & .4911 & -.6758 & .4908 & -.6619 & .4829 \\
\hline NO_HS & $.5397^{\star *}$ & .2083 & $.5976^{\star \pi}$ & .2056 & $.7242^{\star *}$ & .2009 \\
\hline HIGH_SCHOOL & .0764 & .1614 & .1337 & .1579 & .2503 & .1537 \\
\hline SOME_COLL & -.1806 & .1507 & -.1415 & .1488 & -.0342 & .1447 \\
\hline NOMARRY & -.0325 & .1492 & -.0134 & .1488 & -.0740 & .1461 \\
\hline DIV_SEP & .0404 & .1223 & .0536 & .1223 & .0580 & .1200 \\
\hline BADNEWS & $.2178^{*}$ & .1257 & $.2135^{*}$ & .1257 & $.4459 \div$ & .1206 \\
\hline FEMALE & .0917 & .0960 & .0958 & .0959 & $.1828^{*}$ & .0933 \\
\hline
\end{tabular}

The table is continued on the following page. 
Table 7 (continued)

ANXIETY AND THE PROBABILITY OF EMPLOYMENT (ALL HOUSEHOLDS)

(Unweighted Michigan data; June through December 1995, excluding September)

\begin{tabular}{|c|c|c|c|c|c|c|}
\hline & \multicolumn{6}{|c|}{ Dependent variable equals 1 if the household is anxious (ANX) and zero otherwise. } \\
\hline & $\begin{array}{l}\text { Coefficient } \\
\text { (1) }\end{array}$ & $\begin{array}{c}\text { Standard error } \\
\text { (2) }\end{array}$ & $\begin{array}{l}\text { Coefficient } \\
\text { (3) }\end{array}$ & $\begin{array}{c}\text { Standard error } \\
\text { (4) }\end{array}$ & $\begin{array}{l}\text { Coefficient } \\
\quad(5)\end{array}$ & $\begin{array}{l}\text { Standard error } \\
(6)\end{array}$ \\
\hline EXP_BUSINESS & $.5715^{* *}$ & .1050 & $.5781^{* *}$ & .1049 & & \\
\hline CUR_BUSINESS & $.5227^{* *}$ & .1059 & $.5230^{* *}$ & .1058 & & \\
\hline SAVINGS & .0537 & .0999 & .0519 & .0999 & & \\
\hline CREDIT & .3116 & .1200 & $.3234 * \star$ & .1197 & & \\
\hline CENS1 & $.6301^{\star *}$ & .2181 & $.6126^{\star *}$ & .2177 & $.5523^{* *}$ & .2139 \\
\hline CENS2 & $.4575^{\star \star}$ & .1677 & $.4196^{* *}$ & .1662 & $.4272^{* *}$ & .1625 \\
\hline CENS3 & -.0212 & .1620 & -.0293 & .1619 & -.0844 & .1586 \\
\hline CENS4 & -.0019 & .2158 & .0254 & .2148 & -.0464 & .2096 \\
\hline CENS6 & -.2610 & .2359 & -.2480 & .2259 & -.3157 & .2327 \\
\hline CENS7 & $.3451^{*}$ & .1885 & $.3635^{\star}$ & .1881 & $.3241^{\star}$ & .1833 \\
\hline CENS8 & -.1262 & .2322 & -.1276 & .2320 & -.0904 & .2273 \\
\hline CENS9 & $.6641^{* *}$ & .1755 & $.6381^{* *}$ & .1747 & $.6055^{* *}$ & .1705 \\
\hline $\begin{array}{l}\text { Memo: } \\
\text { Likelihood ratio } \\
\text { test }\end{array}$ & 325.965 & $\mathrm{p}=.0001$ & 211.922 & $\mathrm{p}=.00011$ & 217.581 & $\mathrm{p}=.0001$ \\
\hline
\end{tabular}

** Indicates significance at the 5 percent level using the Wald test with a chi-squared distribution.

* Indicates significance at the 10 percent level.

The sample size is 2,732 households. 
Table 8

LOGIT REGRESSIONS FOR THE LIKELIHOOD OF ANXIETY USING 1988 AND 1995 DATA (Unweighted Michigan data; June-December 1995, excluding September; July-December 1988)

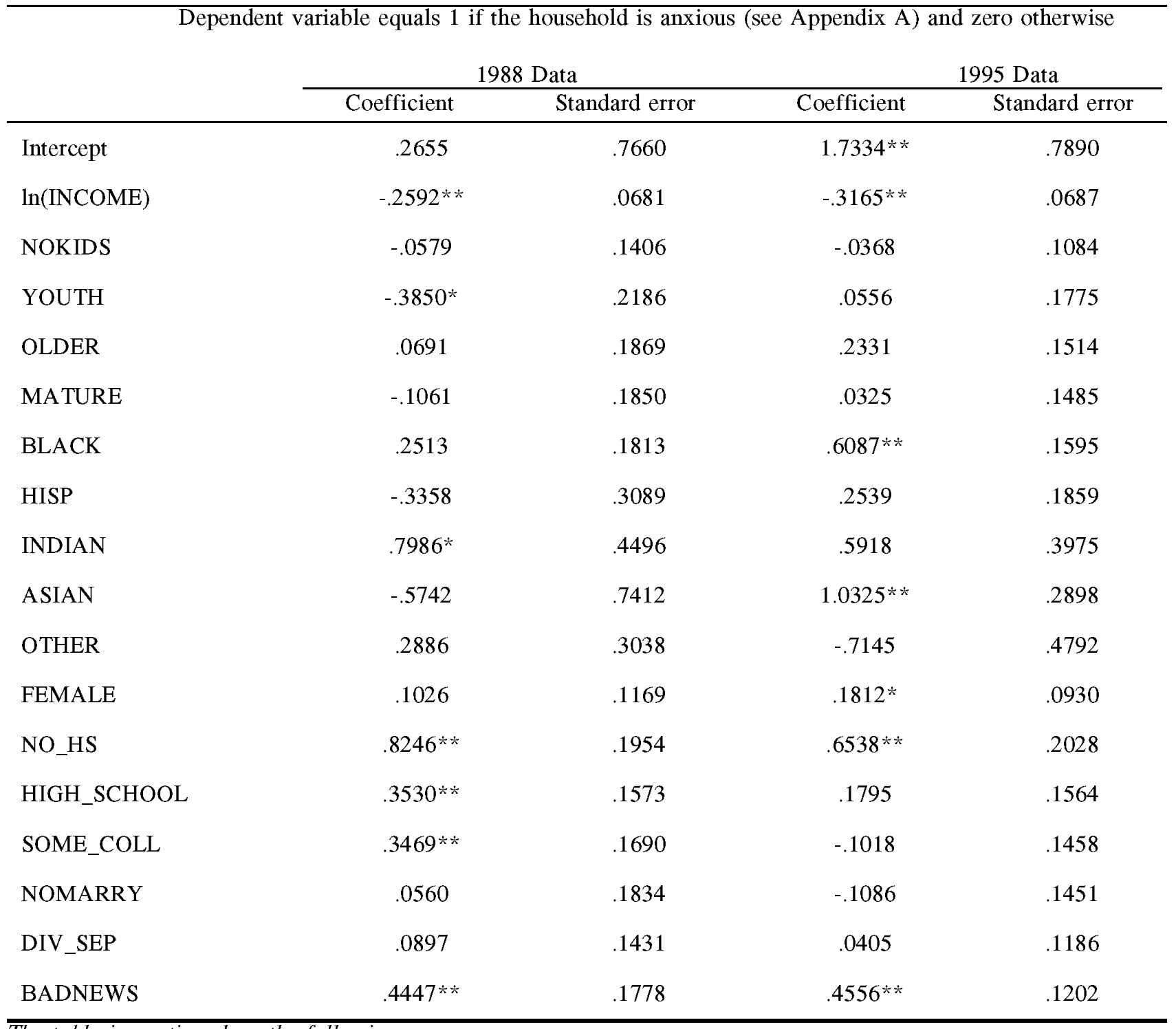

The table is continued on the following page. 
Table 8 (continued)

LOGIT REGRESSIONS FOR THE LIKELIHOOD OF ANXIETY USING 1988 AND 1995 DATA (Unweighted Michigan data; June-December 1995, excluding September; July-December 1988)

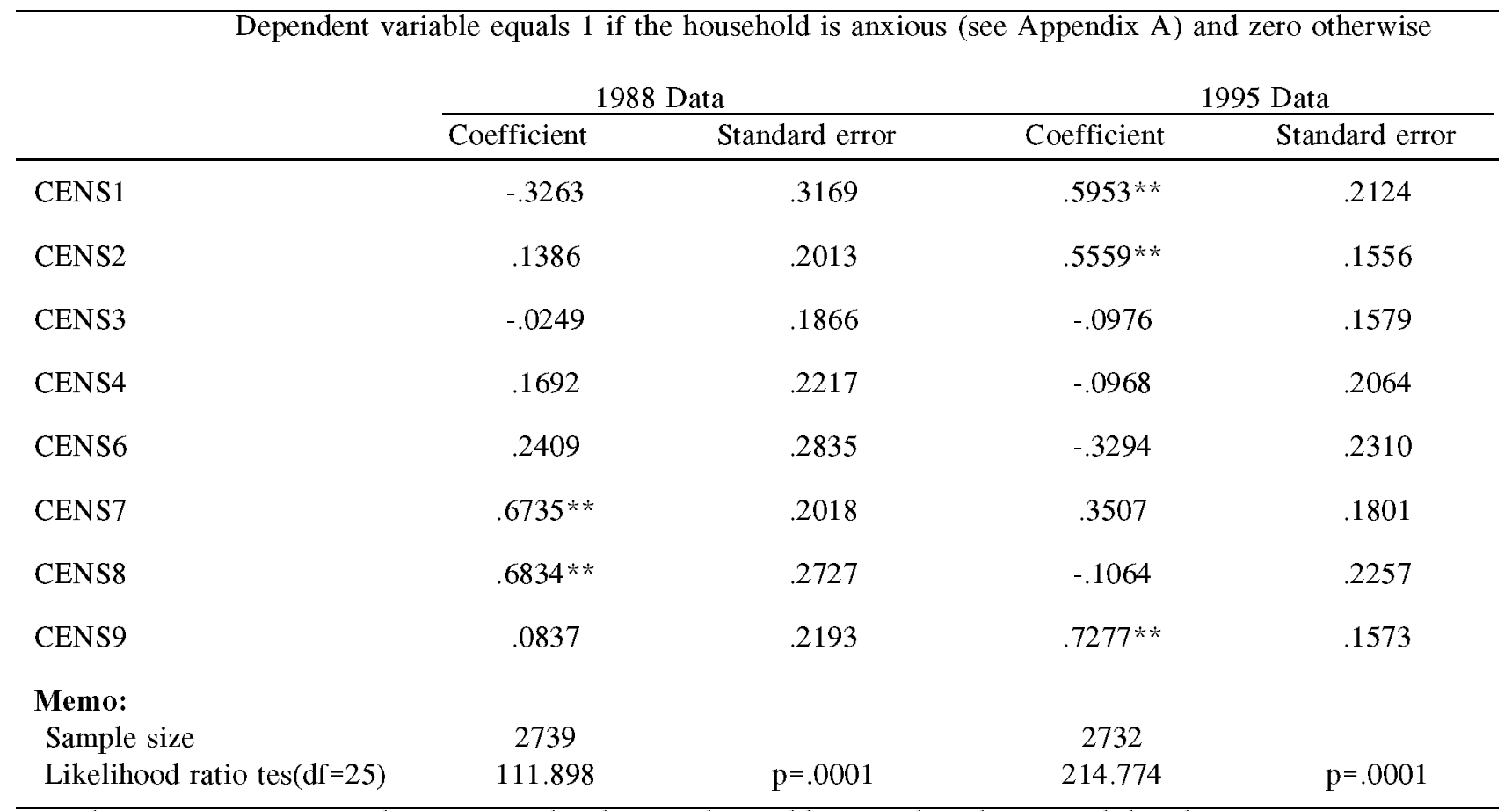

$* *$ Indicates significance at the 5 percent level using the Wald test with a chi-squared distribution.

* Indicates significance at the 10 percent level. 
Chart 1

\section{SURVEYS OF OVERALL CONSUMER CONFIDENCE}

Michigan SRC Index of Consumer Confidence

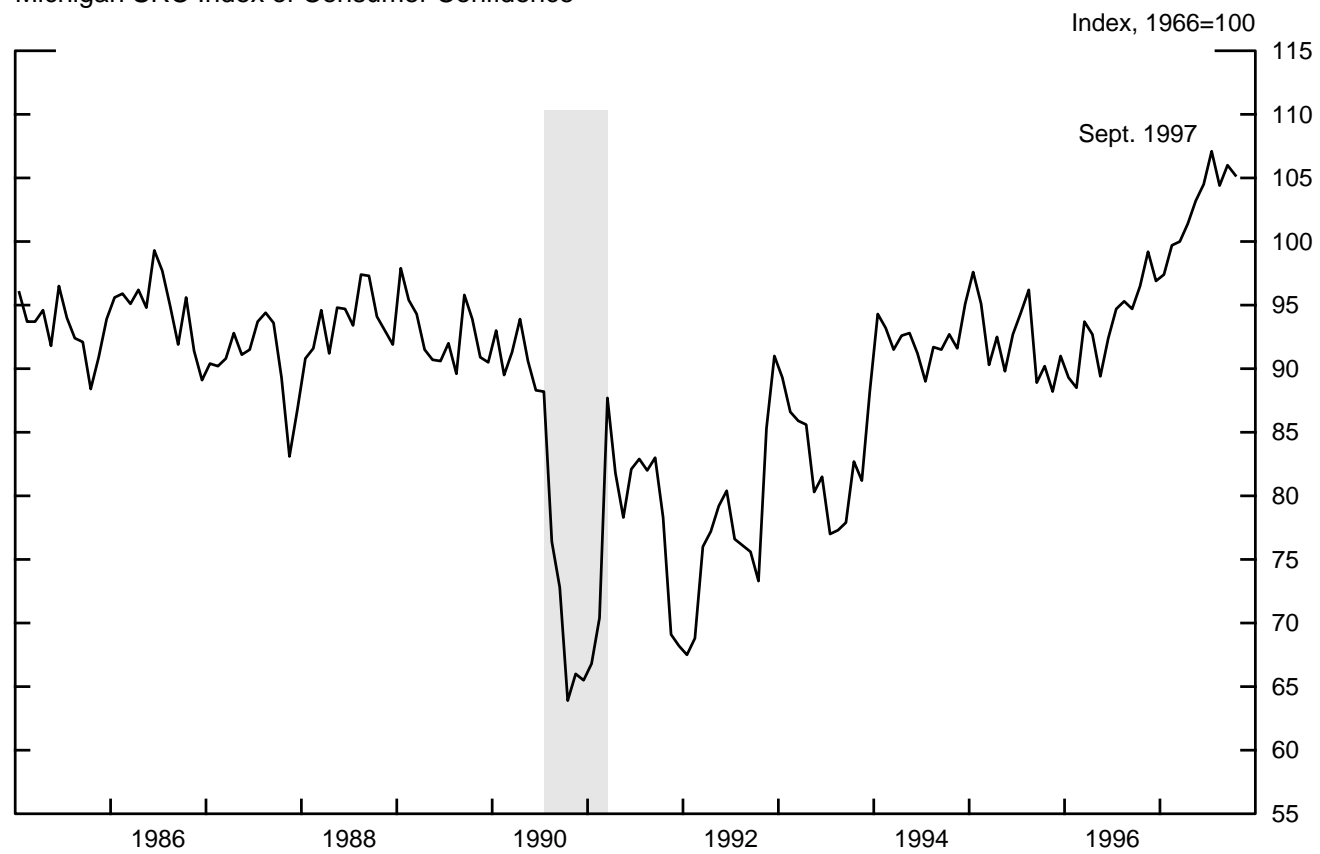

Conference Board

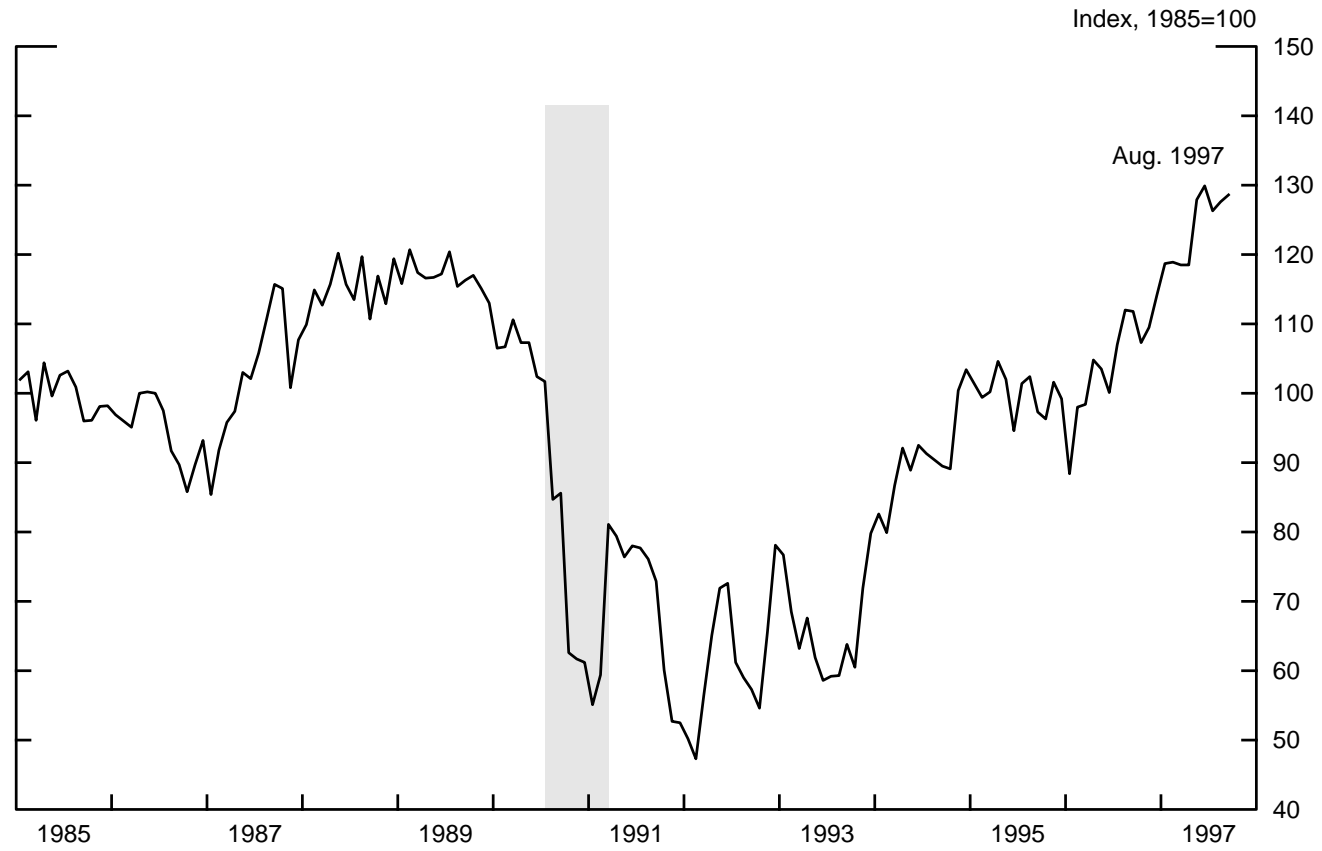


Chart 2

PROBABILITY OF EMPLOYMENT FROM CPS AND MICHIGAN DATA

(Generated using weighted observations)

Distribution of Households' Probability of Employment

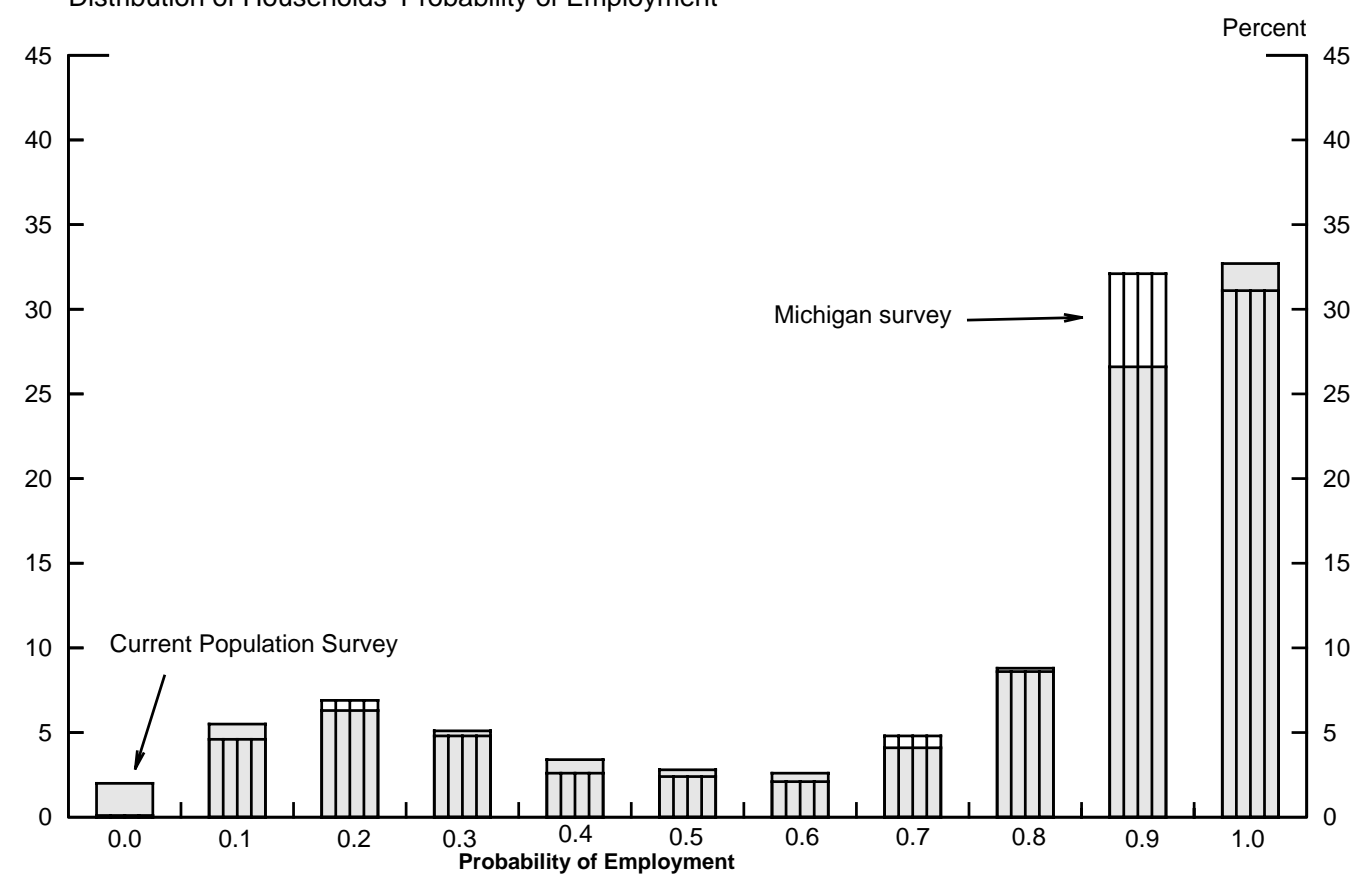

Cumulative Distribution of Households' Probability of Employment

Cumulative percent

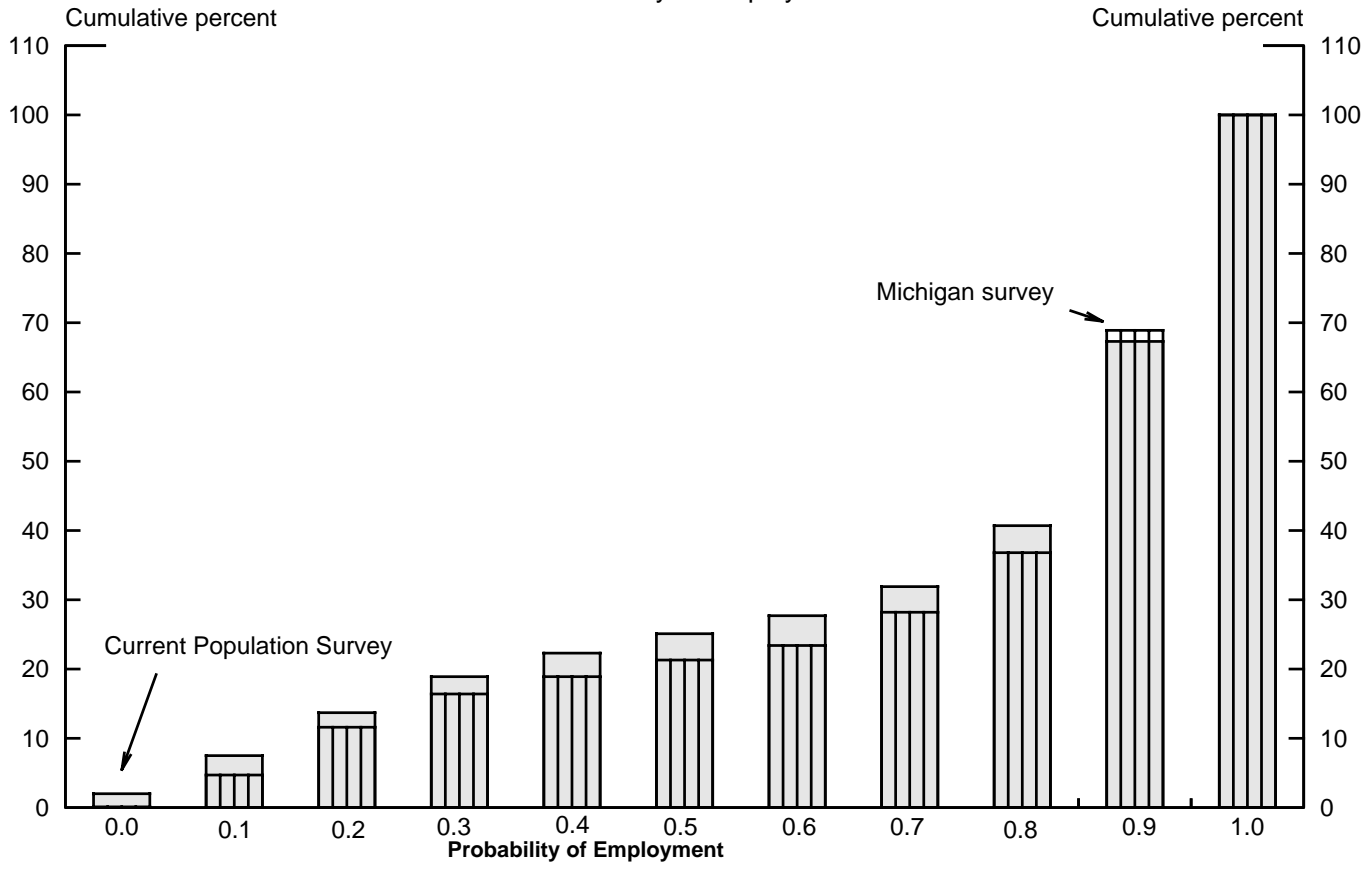


